\title{
Airport Selection Criteria of Low-cost Carriers: A Fuzzy Analytical Hierarchy Process
}

Hui Shan $\mathrm{LOH}^{1}$, Kum Fai YUEN ${ }^{2}$, Xueqin $\mathrm{WANG}^{3 *}$, Ebru SÜRÜCÜBALCI $^{4,5}$, Gökcay BALCI6 ${ }^{5}$, \& Qingji ZHOU ${ }^{2}$

${ }^{1}$ Logistic \& Supply Chain Management Programme, Singapore University of Social Sciences, Singapore

${ }^{2}$ School of Civil and Environmental Engineering, Nanyang Technological University, Singapore

${ }^{3}$ Ocean College, Zhejiang University, Zhoushan, China

${ }^{4}$ School of Management, University of Bradford, Bradford, United Kingdom

${ }^{5}$ Faculty of Business, Manisa Celal Bayar University, Manisa, Turkey

${ }^{6}$ Huddersfield Business School, University of Huddersfield, United Kingdom

*Corresponding author, E-mail: xueqin.wang@,zju.edu.cn 


\title{
Airport Selection Criteria of Low-cost Carriers: A Fuzzy Analytical Hierarchy Process
}

\begin{abstract}
The selection of airport is an important consideration for low-cost carriers (LCCs) to remain cost competitive. The objective of this study is to identify and rank the airport selection criteria of LCCs. Based on reviewing the existing literature, five main factors comprising 16 sub-factors were developed. The factors were first validated by three industry experts from the aviation industry. Thereafter, a survey questionnaire requiring a comparison of the factors was administered on 28 executives who were involved in the strategy planning and formulation of LCCs based in China or Korea. The collected data were analysed using fuzzy analytical hierarchy process (FAHP). In descending order of their importance, the main factors influencing LCCs' selection of airport are (1) airport charges, (2) airport performance, (3) airport growth opportunities, (4) catchment area and (5) airport infrastructure. The top three sub-factors are airport costs, demand for LCC services and passenger throughput. The research contributes to academic research by providing a holistic assessment of the key considerations influencing LCCs' selection of airport. In addition, it implicates policy formulation of LCCs by providing a framework for assessment of airports that are suitable for LCCs' operations.
\end{abstract}

Keywords: low-cost carriers; airport selection criteria; FAHP;

\section{Introduction}

The deregulation of aviation industry in the 1990s has led to a strong development of Low-cost carriers (LCCs), especially in Europe and North America. LCCs are often defined as the airlines that are operated to minimise operating costs and without the conventional in-flight services and amenities (i.e. no-frills), resulting in lower fares and fewer comforts. The traditional business model of LCCs has been well studied (Halpern et al., 2016; Klophaus et al., 2012). Compared to Full-Service Carriers (FSCs), LCCs are often characterised by pointto-point traffic, single aircraft type, use of secondary airport, direct sales of tickets, single class cabin, and no complimentary in-flights services. Due to their price competitiveness, LCCs have not only displaced considerable market share from FSCs, but also stimulated demand from new 
market segments (Zhang et al., 2008). In fact, about 50\% of the intra-European air traffic is served by LCCs in 2014. While the early booming period of the LCC sector has been replaced with a steadier growth in recent years, the sector remains an important part of the aviation industry.

Among others, airport choice is one of the most important factors that determines the success or failure of LCCs (Warnock-Smith and Potter, 2005). In this regard, research has been conducted to identify the airport selection criteria, yet no consensus has been reached regarding their relative rankings. For example, Mason and Morrison (2008) evaluated the attractiveness of airports based on airport cost, airport size, number of competing airlines and monopoly routes, whereas other studies prioritised the criteria such as efficient turnaround facilities, catchment area and proximity to the primary city (Barrett, 2004b; Warnock-Smith and Potter, 2005). Dziedzic and Warnock-Smith (2016a) further suggested that the relative importance of the selection criteria has changed over the years given the fast-evolving business environment.

Indeed, clear distinctions between different airline business models are increasingly hard to formulate considering the dynamic nature of the industry. LCCs are actively modifying their strategies in order to stay competitive by blending low-cost traits with those of FSCs (Klophaus et al., 2012). Notable changes are witnessed within the LCC sector, which include more focus on attracting business travellers (hence moving into primary airports and requiring short flight connections), engaging in code-sharing and even offering long-haul services (De Poret et al., 2015; Halpern et al., 2016). To a certain extent, the LCC sector seems to drift to a hybrid model where factors related to connectivity, convenience and comfort become important considerations in addition to the conventional emphasis on cost and efficiency (Mason and Morrison, 2008). To this end, the traditional LCC business model has evolved as the sector matures. It is thus highly timely to re-examine the airport selection criteria under the current changing context of LCCs.

Furthermore, extant studies predominantly focus on LCCs in Europe and North America, whereas LCCs in Asia are under-investigated (Chang and Lee, 2010; Zhang et al., 2008). As different from those mature markets, LCCs in Asia are only a recent phenomenon due to a much slower pace of deregulation in the region. According to International Civil Aviation Organization (ICAO), there have been many, recent entrants in Asia's LCC market (e.g. 9 Air, Air Seoul, Lucky Air, NokScoot Airlines, Spring Airlines Japan, Thai Viet Jet Air and Trujet). This would raise competition between LCCs operating in Asia. Further, Asia is a fast- 
developing economic region. The income of Asia's population is increasing, and this would have an impact on passengers' expectation about the services of LCCs and subsequently, their airport selection choices. As a consequence of the above observations, insights generated from prior research may not be applicable to the unique economic, operating and regulatory environment of Asia. To this end, an Asian perspective becomes critical, which is especially true considering the huge growth potential of the Asian aviation market. To overcome the research gap, this study aims to identify and prioritise the airport selection criteria from the perspective of Asian LCCs. Methodology-wise, a Fuzzy Analytical Hierarchy Process (FAHP) is applied in order to systematically rank the relatively importance of the selection criteria. The method integrates the fuzzy logic into the conventional AHP technique which allows the researchers to handle vague information based on the experts' judgements to determine priority scales.

The remainder of this paper is organised as follows. First, extant literature related to the LCC operating models is reviewed, based on which the key airport selection criteria along with the sub-criteria are presented. After elaborating the research method, the results regarding the relative importance of the selection criteria are discussed in detail. It is found that airport charges is the most important criterion, followed by airport performance and airport growth opportunities, whereas the airport infrastructure and catchment area are considered least important. Finally, this study is concluded by discussing the contributions, implications and limitations.

\section{Literature Review}

\subsection{LCC operating model}

The evolution of the airline industry then saw emergence of the LCCs in the 1990s (Dziedzic and Warnock-Smith, 2016b). The increasing presence of low-cost airlines is closely linked to the deregulation of the aviation industry. For example, almost $50 \%$ of the intra-European traffic is served by LCCs in 2014 (European Low Fares Airline Association, 2015). Traditionally, to remain cost effective, LCC employs single-class aircrafts for point-to-point routes from secondary airports (Forsyth, 2003; Zhang et al., 2008). Other characteristics of a typical LCC include high seating density, high aircraft utilisation, high crew utilisation, short and mediumhaul routes and no frills service (Halpern et al., 2016). Today, the LCC sector continues to grow rapidly (Gross and Lück, 2016). As such, the sector has seen eminent changes such as increased flexibility in ticket sales and boarding, code sharing arrangements, additional 
services and venturing into long-haul operations (De Poret et al., 2015; de Wit and Zuidberg, 2012; Klophaus et al., 2012).

The airline network can be in the form of a hub-and-spoke network or point-to-point network and its design is crucial for carriers. Hsu and Wen (2002) developed a reliability evaluation method for airline network design and the results revealed that fluctuations in passenger demand is the most critical risk that LCCs should pay attention to. To address this problem, LCCs ought to provide measures that can improve flexibilities in airline flight frequencies which can be done through proper designing of the airline network. In addition, the competition between airports and airlines adds complication to the selection criteria of LCCs. Fu et al. (2006) employed a duopoly model to analyse and capture the differential competitive effects of changing airport user charges on FSAs and LCCs. The results revealed that an LCC loses its output and profits more than a competing FSA and that a higher airside fee can enhance the competitive advantage of an FSA against a competing LCC.

It is noted that lines between LCCs' and FSAs' business models are blurring (Klophaus et al., 2012). This trend is coined as hybridisation where some LCCs are modifying their strategy to adopt service features of FSAs whereas some FSAs are too adjusting their prices and service features to appeal to cost-conscious, short-haul passengers. While lines are blurring between the two business models, it was warned that LCCs must prioritise on reducing cost (https://centreforaviation.com/analysis/reports/lcc-experiences-how-was-it-for-youhybridisation-and-airlines-in-transition-144868). The consideration to include or adopt features from FSA should only come after cost reduction. This warning resonates with Porter's generic strategies where business firms should only pursue a low-cost or differentiation strategy to gain a competitive advantage in the market (Porter and Kramer, 2017). Attempting to pursue both strategies simultaneously runs into the risk of being 'stuck in the middle' where a firm could neither offer high value for money nor distinctive services. In this regard, the airport selection criteria of FSAs or LCCs are to a large extent, distinct whereby the former chiefly focuses on criteria that strengthen their differentiation competitive advantage and the latter mainly focuses on criteria that help reduce cost.

However, for LCCs, many have realised that they are no longer able to compete purely on price and have rediscovered the idea of offering 'frills' in their services such as seat reservations or frequent flyer programs (https://www.prologis.aero/competences/low-cost-and-hybrid-airlinebusiness/). They are also focusing on making ancillary revenue and improving customer 
relationship management without diluting their core cost competitive advantage. This shift towards developing a hybrid business model by LCCs has called for a renewed interest in their airport selection criteria which not only focuses on cost but also providing additional services, making ancillary revenue and improving customer relationship management. These factors shall be considered in the design of the LCCs' airport selection criteria.

\subsection{Perspective of LCCs}

The rapid growth of LCCs in the airline industry has reshaped the competitive environment by transforming airport selection decisions. As a result, research in airport selection from the perspective of LCCs have become popular, especially in the recent decade. For the airports, increasing LCC traffic is important in gaining higher point-to-point traffic (Scheers, 2001) and one way of doing so is to provide convenient slot times and spare capacity at the airport (Calder, 2002). On the other hand, the main factors that affect airport selection by LCCs are mainly related to the infrastructure, cost of service at the airport and the location of the airport. These include quick turnaround times, high aircraft utilisation, lack of congestion (Calder, 2002; Pitt and Brown, 2001; Warnock-Smith and Potter, 2005), the ability to reduce cost and offer flexibility in negotiating deals (Barrett, 2004a; Gillen and Lall, 2004), aeronautical charges (Francis et al., 2003; Warnock-Smith and Potter, 2005), catchment area (Warnock-Smith and Potter, 2005) and accessibility of airport (Dobruszkes, 2006). In particular, it was found that low airport charges, quick turnarounds, simple terminals, rapid check-in facilities, good passenger facilities and accessibility were the major criteria when Ryanair selected their airports (Barrett, 2013). In another study, Malighetti et al. (2009) concluded that Ryanair chose to cooperate with secondary airports as discounted fares were available. This finding corroborates with other studies that see the increasing trend of airports offering discounts as incentives to attract LCCs (ACI-Europe, 2015; Jones et al., 2013; Malina et al., 2012).

Taking on a more strategic view, studies have suggested that the competition at the airport (Mason and Morrison, 2008) and maturity level of the market (Fageda et al., 2015) can also influence airport selection by LCCs. With LCCs progressively shifting to primary airports in recent years (Dziedzic and Warnock-Smith, 2016b), code-sharing with network carriers becomes viable (Fageda et al., 2015; Halpern et al., 2016) and this enables LCCs to better compete with other carriers. More specifically, Warnock-Smith and Potter (2005) found that the most important factors affecting airport choice are high demand for LCC services, quick 
and efficient turnaround facilities and convenient slot times. On the other hand, the lowest ranked factors are good non-aeronautical revenues, good experience of LCCs and high level of airline competition. Recently, Dziedzic and Warnock-Smith (2016b) have updated this list of airport choice factors with more relevant choice factors incorporated through trade press.

\subsection{Perspective of passengers}

Perceptions of passengers are also important as airlines seek to serve the needs of their customers ultimately. Numerous studies investigated passengers' airport selection criteria from different regions. The most important factors influencing airport selection by passengers are found to be fare, flight frequency, access time and cost as well as experience with the airport (de Luca and Di Pace, 2012; Loo, 2008; Lu et al., 2011). Passengers are willing to travel further to gain access to cheaper fares (Humphreys and Francis, 2002). This shows that there is lesser emphasis on the catchment area and accessibility. In a study by Chiou and Liu (2016), it was found that the passengers' attitude towards FSCs and LCCs are different, with service value exerting the most significant effects during selection decisions made by LCC passengers. The results of another study targeting business travellers indicated that passengers compare FSCs and LCCs to evaluate the best airline to fly with (Evangelho et al., 2005). Additionally, business travellers view service attributes such as frequent flyer programs, the schedule/frequency of flights; in-flight service and business lounge options as very important criteria when selecting between FSCs and LCCs (Thanasupsin et al., 2010).

In summary, Table 1 displays the main selection criteria gathered from literature taking into account the operating landscape of the LCCs as well as the perspectives of its management and passengers. A review of the literature reveals that although airport choice factors for LCCs have been investigated, there has yet to be a rational framework to facilitate decision making at the management level. Hence, this paper addresses this gap by examining airport selection criteria of LCCs through an application of the FAHP.

\section{Methodology}

This research conducts fuzzy analytical hierarchy process (FAHP) to determine the relative importance weights of airport selection factors. The AHP is a multi-criteria decision method that implements a pair-wise comparison based on the judgement of experts to determine 
priority scales (Saaty, 2008). Since AHP is a convenient and easy to use yet an effective tool for measuring multiple criteria, it has been utilized in several areas. However, scholars raise concerns on the classic AHP method as it may not reflect human logic in which uncertainty and subjectivity may occur with the factor comparisons (Kahraman and Kaya, 2010). That is, respondents may not be certain with regards to the importance level of each factor in some cases (Kilincci and Onal, 2011). To overcome this problem, the classic AHP methodology has been improved by the utilization of fuzzy logic (Emrouznejad and Marra, 2017). It overcomes the problem by allowing researchers to handle vague information and achieve improvements in case of an imprecise ranking (Kahraman and Kaya, 2010; Sofyalığlu and Kartal, 2012). FAHP has been used in various disciplines including health sector, business, engineering, and environmental science (Emrouznejad and Marra, 2017). Studies in different transportation areas also apply FAHP such as in air transportation (Karaman et al., 2018), cruise port selection (Wang et al., 2014), and seaport selection (Balci et al., 2018).

Accordingly, we applied FAHP method in this study to determine the weights of factors and sub-factors. Our research consists of four steps as illustrated in Figure 1.

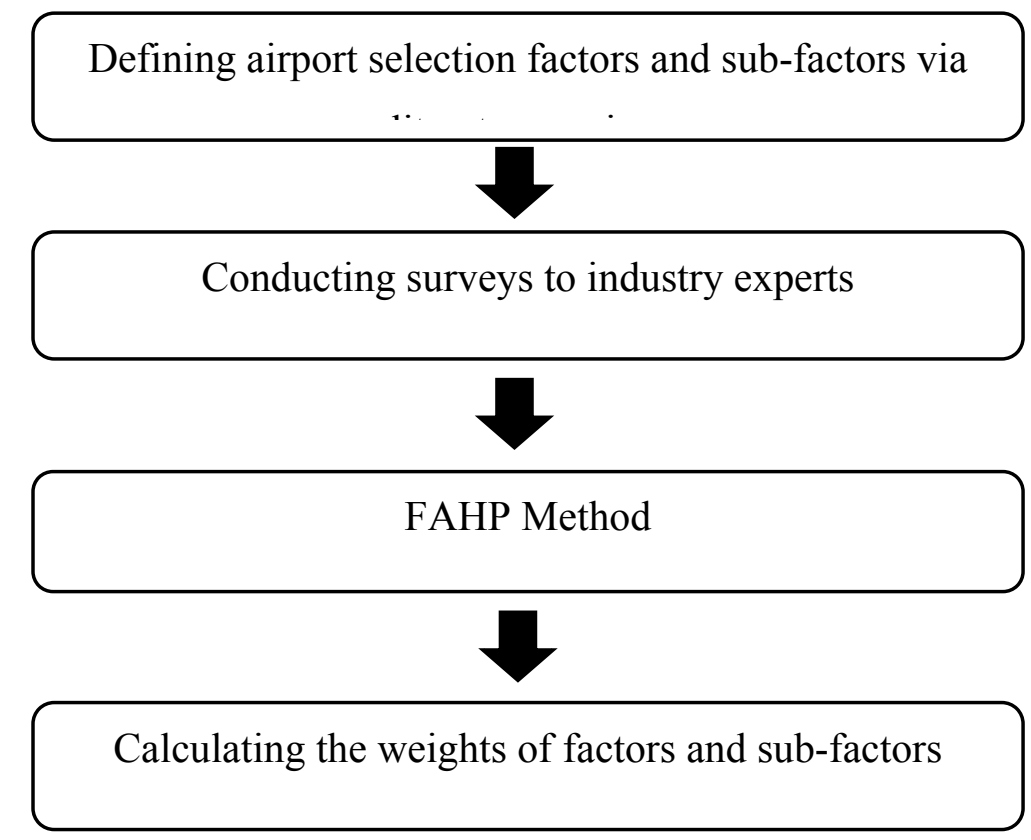

Figure 1. Research methodology for airport selection 
Resource: Compiled by authors

Step 1: Defining airport selection main factors and sub-factors via literature review

In the first step, we have created the airport selection criteria based on the literature review. Our criteria consist of five main factors including 16 sub-factors. Table 1 shows the factors, sub-factors, description of the sub-factors, and the previous studies using these factors. The factors are validated by three industry experts who have at least 20 years of working experience in LCCs from Asia. Further, they are holding senior management roles and are directly involved in strategy formulation and planning.

\section{$<$ INSERT TABLE 1 HERE $>$}

\section{Step 2: Conducting surveys on industry experts}

After deciding the factors and sub-factors, we formed an AHP questionnaire. In the questionnaire, the questions were asked to rate on a nine-point scale, which is developed by Saaty (2008), for the pairwise comparison of the factors and sub-factors. The standardized one to nine AHP scale is provided in Table 2.

\section{<INSERT TABLE 2 HERE $>$}

The sampling frame comprises all LCCs in China and Korea. Through the connection of the third author who identified the liaison officers and the contact details of each LCC, the liaison officers were contacted and invited to participate in a survey. Among the 10 LCCs domiciled in China and six domiciled in Korea, tThe LCCs accepting the invitations are Spring Airline (China), Capital Airlines (China), Juneyao Airlines (China), Jeju Air (Korea), Air Seoul (Korea), and Air Busan (Korea). These airlines are among the largest LCCs in terms of number of routes and airplanes in China and Korea, hence representing a significant portion of LCC market share (https://www.icao.int/sustainability/Documents/LCC-List.pdf). The liaison officers were requested to send the survey questionnaires to personnel who are involved in strategy formulation or planning, or any others who they deem as qualified to complete the questionnaire. Table 3 below shows the profile of the survey respondents.

\section{$<$ INSERT TABLE 3 HERE $>$}

Step 3: FAHP method 
After the data collection process was completed, we transformed crisp numbers to fuzzy numbers with Angnostopoulos et al.'s (2007) developed scale. Table 4 shows the one to nine fuzzy conversion scale.

\section{$<$ INSERT TABLE 4 HERE $>$}

Let us assume that (M) is a crisp number and enlarge triangular number as $l, m, u . l$ means the minimum possible value while $m$ means for the optimum value. $u$ means the maximum possible value (Kahraman et al., 2004). Moreover, $X=\left\{X_{1}, X_{2}, \ldots \ldots \ldots X_{n}\right\}$ ( $X$ defines as a criteria set and $G=\left\{g_{1}, g_{2}, \ldots \ldots . g_{n}\right\}$ defines as sub-criteria set. Then the extent analysis of Chang (1996) is implemented for each factor and sub-factor. Thus, each $m$ number gets an extent analysis value. The values are displayed as below:

$M_{g i}{ }^{l}, M_{g i}{ }^{2}, \ldots \ldots \ldots . ., M_{g i}{ }^{m}$

Each value of $M_{g i}^{j}(i=1,2, \ldots n$ and $j=1,2, \ldots . m)$ is a triangular fuzzy number.

After setting fuzzy numbers, we applied Chang's (1996) extent analysis to determine fuzzy synthetic values.

The fuzzy synthetic values are shown below considering the criterion $i$ :

$S i=\sum_{j=1}^{m} M_{\mathrm{gi}}^{\mathrm{j}} \otimes\left[\sum_{i=1}^{n} \sum_{j=1}^{m} M \mathrm{gij}\right]^{-1}$

Here, to obtain the value of $\sum_{j=1}^{m} M_{\mathrm{gi}}^{\mathrm{j}}$ fuzzy addition is used for $\mathrm{m}$ extent analysis value.

$$
\begin{aligned}
& \sum_{j=1}^{m} M_{\mathrm{gi}}^{\mathrm{j}}=\left(\sum_{j=1}^{m} l j, \sum_{j=1}^{m} m j, \sum_{j=1}^{m} u j\right) \\
& \sum_{i=1}^{n} \sum_{j=1}^{m} M_{g i}{ }^{m}=\left(\sum_{j=1}^{m} l j, \sum_{j=1}^{m} m j, \sum_{j=1}^{m} u j\right)
\end{aligned}
$$

After these calculations, the reverse of the vector is calculated via the following formula:

$$
\left[\sum_{i=1}^{n} \sum_{j=1}^{m} M g i j\right]^{-1}=\left(\frac{1}{\sum_{i=1}^{n} u i}, \frac{1}{\sum_{i=1}^{n} m i \sum_{i=1}^{n} l i}\right)
$$


Defuzzification process is calculated using Liou and Wang (1992)'s method. $\alpha$ means the degree of optimism of the expert and gets value between zero and one. When the $\alpha$ gets higher values, it means that a higher degree of optimism is reached. In this study, to be neutral, we take $\alpha$ as 0.5 . After choosing the $\alpha$, we calculated the weight of criteria and sub-criteria.

$I_{T}^{\alpha}(M)=\frac{1}{2} \alpha(m+u)+\frac{1}{2}(1-\alpha)(l+m)=\frac{1}{2}[\alpha u+m+(1-\alpha)]$

Step 5: Calculating the weights of factors and sub-factors

To calculate the weight of the main criteria, we formed the fuzzy comparison matrix according to Angnostopoulos et al. (2007)'s proposed linguistic scale.

\section{<INSERT TABLE 5 HERE $>$}

Fuzzy synthetic values for airport selection criteria for LCCs are calculated based on the first formula as follows:

$$
\begin{array}{ll}
\mathrm{S}_{\mathrm{F} 1}=(0.2236,0.2916,0.3728) & \mathrm{S}_{\mathrm{F} 2}=(0.1179,0.1496,0.1933) \\
\mathrm{S}_{\mathrm{F} 3}=(0.0927,0.1151,0.1466) & \mathrm{S}_{\mathrm{F} 4}=(0.1777,0.2278,0.2912) \\
\mathrm{S}_{\mathrm{F} 5}=(0.1676,0.2160,0.2791) &
\end{array}
$$

The Index of optimism for each criterion is calculated with the fifth equation.

$$
\begin{array}{ll}
\mathrm{I}_{\mathrm{F} 1}=0.5898 & \mathrm{I}_{\mathrm{F} 2}=0.3053 \\
\mathrm{I}_{\mathrm{F} 3}=0.2346 & \mathrm{I}_{\mathrm{F} 4}=0.4623 \\
\mathrm{I}_{\mathrm{F} 5}=0.4394 & \\
\hline
\end{array}
$$

At the final step, we calculated each criterion's weight with dividing the total indexes of optimism to each criterion's index of optimism.

$$
\begin{array}{ll}
\mathrm{W}_{\mathrm{F} 1}=\frac{0.5898}{2.0312}=0.29 & \mathrm{~W}_{\mathrm{F} 2}=\frac{0.3053}{2.0312}=0.15 \\
\mathrm{~W}_{\mathrm{F} 3}=\frac{0.2346}{2.0312}=0.12 & \mathrm{~W}_{\mathrm{F} 4}=\frac{0.4623}{2.0312}=0.23 \\
\mathrm{~W}_{\mathrm{F} 5}=\frac{0.4394}{2.0312}=0.22 &
\end{array}
$$


We applied the same processes for each of the sub-factor as well. Each sub-factor's fuzzy comparison matrix is shown in the Appendix.

\section{Results}

The ranking of the factors will be discussed in this section. According to the AHP methodology, the ranking for the criteria is shown in Table 6. Of the 5 main factors, Airport Charges is the main factor that obtained the highest value of fuzzy weight of 0.29 and consequently, it is the most important factor in the decision-making process of LCCs in their selection of airports. The next most important factors are Airport Performance, Airport Growth Opportunities and Catchment Area, with weights $0.23,0.22$ and 0.15 respectively. It is observed that Airport Performance and Airport Growth Opportunities almost share the same fuzzy weights, with a difference of only 0.01 . The least most important factor is Airport Infrastructure, with the lowest fuzzy weight of 0.11 . Table 7 shows the weights and overall ranking of the 16 subcriteria and their respective criteria.

\section{$<$ INSERT TABLE 6 \& 7 HERE $>$}

\subsection{Airport Charges}

An examination of the overall ranking of the factors in Table 7 reveals that the factors directly affecting LCCs' cost of operations matter the most to them in their selection of airports. This is in line with the LCC business model which focuses on driving down airlines' costs. Hence, Airport Costs is the most important factor overall. Passengers' primary expectations of LCCs which are to provide low air fares impel LCCs to source for cost-saving measures. These can be in the form of incentives and flexibility in deal negotiations with the airports, which are ranked $4^{\text {th }}$ and $8^{\text {th }}$ respectively. Such findings highlight LCCs' significant focus on costs as this will enable them to operate at reduced costs, providing air travel affordability to its targeted passengers.

When compared with the results of Dziedzic and Warnock-Smith (2016) where the only factor related to charges was ranked the most important, the results presented in this study define the 
ranking of different facets of charges for LCCs. Not surprisingly, the Incentives for Cost Reduction is the second most important charges-related sub-criterion, and the $4^{\text {th }}$ most important overall. As compared to Flexibility in Negotiating Airport Charges Deals, LCCs prefer a relatively straightforward way of reducing airport costs, that are through direct airport costs reduction and incentives to bring charges down. However, airport incentive schemes are sometimes offered via public funds which would necessitate the involvement of governments in the discussions, thereby complicating and slowing down the process before an agreement can be reached. Furthermore, authorities and regulators have to ensure that incentives comply with applicable laws and policies, since incentives are viewed as price discrimination and may inhibit competition. It is not uncommon that incentive schemes can take the form of bilateral agreements between airlines and authorities in addition to airport-airline agreements. Hence, different incentive agreements are expected to contain varied provisions as they seek to stimulate development of aircraft or passenger traffic. While Flexibility in Negotiating aAirport Charges $\perp$ eals can assist LCCs in reducing costs ultimately, this does not offer a regular and assured financial protection. The negotiating power of either party is expected to be tagged to those involved in concluding the contracts. When employing negotiation as a tool to reduce costs, the airline and airport management should be aware that there is a risk of losing their negotiating position when key employees directly involved in the negotiation process leave the organisation.

\subsection{Airport Performance}

The second most important criterion is Airport Performance. It has two sub-criteri Passenger Throughput and Efficiency of Aircraft-related Processes, which are the $3^{\text {rd }}$ and $9^{\text {th }}$ most important sub-criteria respectively. It is understandable that Airport Performance in terms of Passenger Throughput is one of the highest ranked sub-criteria as it is indicative of possible operational congestions for the LCCs. As compared to the past where secondary airports would be a natural and intuitive choice for LCCs, these carriers have increasing ventured into operating at primary airports. Unlike FSCs, LCCs operate a simplified fleet and this makes efficiency of aircraft relatively more valued than most other passenger-related performance aspects. This is especially true for short-haul operations which tend to see competition from other transport modes on top of competing carriers. Due to the business model of LCCs, congestions and aircraft delays often translate to higher costs particularly in terms of passenger compensation. The remaining three sub-criteria have received three of the lowest rankings with weights close to each other. These sub-criteria do not have direct impact on the operations of 
the LCCs though they contribute much to passengers' experience at the airport. The results are not surprising as it is aligned with the LCC business model.

\subsection{Airport Growth Opportunities}

Airport Growth Opportunities is the third most important criterion, trailing behind Airport Performance. The sub-criteria related to Airport Growth Opportunities are concerned with long term growth, network expansion and sustainability of the LCC. By and large, passenger volumes are crucial to LCCs and this is evident in the $5^{\text {th }}$ most important overall factor Potential Growth in Passenger Traffic at Airport. The importance of Airport Growth Opportunities is expected to be viewed differently by LCCs at a different business phase. Particularly, some LCCs view certain airports with a hub strategy different from secondary airports. For airports aiming to be leading hubs, network is crucial (CAPA, 2012). Connectivity between flights for passengers will have an impact on the seamlessness of the airport. On the same note, LCCs that have entered the phase of market expansion would favour Airport Growth Opportunities more than LCCs trying to keep costs down.

recent development in its customer-oriented initiatives through reorganisation of aircraft seats

(Kim, 2019)

service and a sense of exclusivity, hence showing features of hybridisation model. For LCCS

looking to differentiate their service from their competitors in similar ways, support from

airports with aligned objectives would be necessary.

The result of the sub-criteria Opportunities for Flight Connections having relatively less importance reflects the fact that the focus of most LCCs remains on a point-to-point network model and largely on short-haul routes.

(CAPA, 2015)

have either started their longer haul flights only in 2019, e.g. such as Juneyao Airlines and Jeju

Air, or have begun to look into offering long haul routes (Perrett, 2018 \{Chun, 2019 \#627 \{Chun,

2019 \#627) $\}$. Due to the low fares and ancillary fees, code sharing is less practiced among LCCs. Though code sharing of services is one of the lowest ranked sub-criteria in this study, it is expected to be more common as FSCs and LCCs practice code sharing with each other, especially those under the same group.

(Kim, 
that helps enhance network connectivity of the FSCs and LCCs as well as one also one that exploits network synergies.

\subsection{Catchment Area}

Ranked the fourth most important criteria, Catchment Area consists of two sub-criteria, namely Demand for LCC Services and Proximity to Populated/Tourist Areas, which have been considered to be the $2^{\text {nd }}$ and $11^{\text {th }}$ most important factors overall to LCCs. The sub-criterion Demand for LCC Services indicates the precise market from which the LCCs compete in as well as the potential amount of new traffic that can be projected (Paliska et al., 2016). While reducing costs is still clearly the main objective in their operations, the results show that LCCs have gained keen interest in capturing demand through a favourable airport catchment area. It is interesting to note that the other sub-criterion Proximity to Populated/Tourist Areas is observed to be of much less importance as market share was found to decrease with increasing access time to airports (Paliska et al., 2016). While the results indicate that Proximity to Populated/Tourist Areas does offer the possibility of favourable circumstances for LCCs to capture demand, there exist other alternative ways and transport modes which tourists can explore getting to an area. The importance of this sub-criterion also tends to diminish when the connectivity of an area improves. Hence, it is more challenging to stimulate growth of traffic.

Overall, Catchment Area is a criterion that encompasses passengers who travel for leisure and business. This is contrasted with the past where LCCs devoted their attention on domestic routes and cost-conscious passengers. As they develop,

stretches to capture greater market share and consequently, regional demand (All Nippon Airways Co. Ltd., 2013).

\section{sample of this study as well. The partnership between Juneyao Airlines and ANA provides an opportunity to leverage on ANA's connections, particularly allowing it to extend its reach into (ANA Group, 2018) \\ Through this trend, the business offerings by LCCs have morphed to attract different segments of travellers. At the same time, for airports that are not considered the primary airport of a region, the results have implications for them as well. This is especially relevant for airports situated at remote regions as the passengers are unlikely to have comparable alternatives. As LCCs exploit the airport's}


catchment area, the airports in turn rely on the networks provided by their airlines. This can prevent dominance of one party over the other in the airport-airline relationship, fostering a more collaborative mutually-dependent one.

\subsection{Airport Infrastructure}

Airport Infrastructure comprises two sub-criteria - Availability of LCC-dedicated Facilities and Airport Ground Accessibility, which received an overall ranking of $6^{\text {th }}$ and $10^{\text {th }}$. The development of airport infrastructure to include LCC-dedicated facilities, such as simple and non-luxurious compound and self-service check-ins, is necessary to remain competitive for airports to attract LCCs. It is imperative to note that building facilities, for example a budget terminal, to cater specifically to LCCs might not be the most optimum or cost efficient from the perspective of airports (Toh, 2013). On the same note, Airport Ground Accessibility affects passengers' connections to and from the airports, hence having a direct impact on the accessibility of the airport. This sub-criterion will exert greater impact for passengers who travel for leisure as they tend to carry more baggage and are generally less familiar with getting around. Hence, the importance of this sub-criterion would likely be ranked differently for different routes and is expected to be affected by different customer segments of the airlines. The airport operator should understand that passengers who choose to take LCCs still have the means to spend at the airports. These passengers might have different expectations when it comes to the comprehensiveness and quality of airport infrastructure. In other words, the passengers of LCCs might not have a no-frills expectation for the airports that they are using, like what they have for the LCCs. Optional and limited add-ons onboard may mean that the passengers may need to have meals and shop more at the airport. Hence, while important, Airport Infrastructure is not the most appealing criterion to LCCs. As LCCs evolve further, the airport planners and operators should acknowledge the differences between the needs of LCCs and that of a FSC when constructing or expanding airport facilities. The specific facilities and infrastructure dedicated to LCCs that the LCCs and their passengers value needs to be explored further.

To ensure that both airports and LCCs adapt for the air travel business, the goals and objectives of both parties should be communicated to each other so as to foster cooperation for overall synergetic and mutual benefits.

\section{Conclusion}


Recognising the emerging presence of LCCs in the aviation industry, this study comprehensively evaluates the airport selection criteria from the perspective of LCCs. Five main criteria, that are, airport charges, airport catchment area, airport infrastructure, performance of airport, and growth opportunities of airport, along with 16 sub-criteria are identified as the critical factor that influence the airport selection process. The method of FAHP is adopted to determine the relative importance of the main factors and sub-factors based on experts' opinions.

In line with the traditional business model of the LCCs, it is found that airport charges remain as the most important consideration in the airport selection process. Performance and growth opportunities of airport are ranked as the second and the third important criteria respectively though the difference in the fuzzy weights is small. It suggests an almost equal importance of these two criteria as viewed by the LCC experts. As two representative sub-criteria, passenger throughput and potential growth in passenger traffic at airport obtain the highest internal weights among their respective sub-criteria, indicating the importance of the passenger handling efficiency (performance) and accommodating capacity (growth opportunity) of airports for the LCCs. Finally, airport catchment area and infrastructure receive the lowest fuzzy weights. Our findings create some insights into the LCCs' business model in the changing context of the aviation industry, which make several contributions.

First, we suggest that the pursuit of low-cost strategy is fundamental in the business model of LCCs, and its importance seems unshakeable despite of the rapidly changing service context. This finding is in line with previous research which suggests that the low-cost approach is crucial to ensure the LCCs' profitability, whereas the comfort and convenience related offerings achieve lower yields (Dziedzic and Warnock-Smith, 2016a; Mason and Morrison, 2008). It is evidenced by the highest fuzzy weight received by the criteria of airport charges which consists of sub-criteria regarding the direct airport costs and discount incentives, and the indirect costs in flexibility of negotiation process. It is also supported by the importance of the airport performance factor, which mainly reflects the operational efficiency and proficiency of the airport that influence the revenue generating potential (e.g. aircraft turn-around time) of LCCs. In addition, the criterion of airport infrastructure receives the lowest importance weight among the five criteria. It includes considerations on availability of dedicated facilities and airport ground accessibility. The result seems to suggest that budget travellers are still the main target of LCCs in which case services are more or less compromised. Herein, $\underline{\underline{I n} \text { this regard, the }}$ low-cost philosophy of LCCs seems to be unchallenged despite the trend of hybridisation. 
rather-Rather than the exclusiveness or the luxury of the airport infrastructure, the cost efficiency is the paramount concern of LCCs. The findings again confirm the LCCs' priority focus on cost factors.

Notwithstanding the importance of the low-cost strategy, our results also show that it is not the sole focus of the LCCs. As revealed in the relative high importance attached to the criterion of growth opportunities, LCCs are also actively seeking other opportunities that could further enhance their business model. Among the sub-criteria, opportunities for flight connections and code-sharing of services clearly indicate LCCs' intention to provide extended services to passengers in addition to point-to-point travel. However, the low rankings of these sub-criteria suggest the overall low priority of the criterion related to growth opportunities as compared to cost-saving agenda. The result is partly expected as previous studies also revealed a low penetration level of the co-sharing practice among LCCs (Morandi et al., 2015). In this regard, the finding may suggest an early stage of the hybridisation trend with the LCC sector. In this regard, while the LCCs are gradually integrating some unconventional growth opportunities in their business model, the harsh market competition forces LCCs to fight for survival which deems other growth opportunities secondary. Nonetheless, the development potential of a hybrid LCC model which combines the conventional low-cost features and the unconventional service features should not be underestimated.

Managerially, our study also provides some guidance for the airport operators. More specifically, the airport operators that aim to attract LCCs should understand the unique characteristics of LCCs. While LCCs operate primarily with a cost-saving strategy, they value discount incentives, flexibilities in the negotiation process, and the airport operational efficiency. Thus, airport operators may consider providing LCCs with a comprehensive package which includes not only charges and discounts, but also flexible payment terms that are open for negotiation as the business relationship matures and guarantees on performance levels with compensation strategies if the guaranteed level is not met. Furthermore, LCCs are increasingly integrating new service elements into their business model and expanding to new market segments. To this end, airport operators may facilitate in providing new growth opportunities for the LCCs. For example, by providing shuttle services connecting airports with the nearby traffic points or tourist areas, the airport can increase its accessibility which makes it more attractive to budget travellers. The airport operators can also provide shuttle services between primary and secondary airports, which creates convenient flight connection opportunities that may be attractive to business travellers. While the additional services may 
increase the airport operating costs, the airport operators and LCCs may collaborate to design an optimal cost sharing strategy that takes the mutual interests into consideration.

Finally, our study has several limitations. First, this study is based on the evaluation of five airport selection criteria and the associated sub-criteria. While we consider these as the most critical factors, there may exist more factors that influence the airport selection process. However, due to the pair-wise comparison nature of the AHP method, we are unable to conduct a comprehensive evaluation of all potential criteria. We are thus restricted to the main criteria that are considered most critical.

In addition, the comparison results are based on the opinions of 28 LCC expertsa total of six different airlines in China and Korea accepted participating in our survey. Although these airlines represent an important proportion of market share, inclusion of other LCCs would be more desirable. We collected the data from 28 experts who are in the liaison team memberss of these LCCs. While the sample size of 28 is considered acceptable in AHP-based studies, a larger sample may produce more rigorous results. Our results might also be affected by the fact that these airlines are from two countries which have different cultural and economic structure. Nonetheless, since our sampled LCCs serve in Intra-Asian market and operate in different countries, the problem of cultural difference is considered to be mitigated.

Finally, the service context of LCCs is constantly changing, so are the relative importance of the airport selection criteria. Our study represents a static reflection of the current market situation which still prioritises airport charges and airport performance as the top considerations. Future studies can be conducted from a dynamic perspective

focus towards hybridisation experienced by LCCs from different regions can be compared, which may generategenerating insights of different selection strategies in a changing service context. 


\section{References}

ACI-Europe, 2015. Airport charges survey 2014, Brussels: ACI Europe.

All Nippon Airways Co. Ltd., 2013. Annual Report 2012.

ANA Group, 2018. ANA and Juneyao Airlines Launch Codeshare and Frequent Flyer Partnership.

Anagnostopoulos, K. P., Gratziou, M., \& Vavatsikos, A. P. (2007). Using the fuzzy analytic hierarchy process for selecting wastewater facilities at prefecture level. European Water, 19(20), 15-24.

Balci, G., Cetin, I. B., \& Esmer, S. (2018). An evaluation of competition and selection criteria between dry bulk terminals in Izmir. Journal of Transport Geography, 69, 294-304.

Barrett, S.D., 2004a. How do the demands for airport services differ between full-service carriers and low-cost carriers? Journal of Air Transport Management 10, 33-39.

Barrett, S.D., 2004b. How do the demands for airport services differ between full-service carriers and low-cost carriers? Journal of Air Transport Management 10(1), 33-39.

Calder, S., 2002. No Frills: The Truth Behind the Low-cost Revolution in the Skies. Virgin Books.

CAPA, 2012. Singapore Changi's decision to close budget terminal could backfire as need for third runway grows. CAPA Centre for Aviation.

CAPA, 2015. Beijing Capital Airlines to be China's seventh airline to fly long haul, planning European routes.

Chang, D. Y. (1996). Applications of the extent analysis method on fuzzy AHP. European

Journal of Operational Research, 95(3), 649-655.

Chang, Y.-C., Lee, N., 2010. A Multi-Objective Goal Programming airport selection model for lowcost carriers' networks. Transportation Research Part E: Logistics and Transportation Review 46(5), 709-718.

Chiou, Y.-C., Liu, C.-H., 2016. Advance purchase behaviors of air passengers: A continuous logit model. Transportation Research Part E: Logistics and Transportation Review 93, 474-484.

de Luca, S., Di Pace, R., 2012. Modelling Passenger Departure Airport Choice: Implicit vs. Explicit Approaches. Procedia - Social and Behavioral Sciences 54, 875-885.

De Poret, M., O'Connell, J.F., Warnock-Smith, D., 2015. The economic viability of long-haul low cost operations: Evidence from the transatlantic market. Journal of Air Transport Management 42, 272-281. de Wit, J.G., Zuidberg, J., 2012. The growth limits of the low cost carrier model. Journal of Air Transport Management 21, 17-23.

Dobruszkes, F., 2006. An analysis of European low-cost airlines and their networks. Journal of Transport Geography 14(4), 249-264.

Dziedzic, M., Warnock-Smith, D., 2016a. The role of secondary airports for today's low-cost carrier business models: The European case. Research in Transportation Business \& Management 21, 19-32.

Dziedzic, M., Warnock-Smith, D., 2016b. The role of secondary airports for today's lowcost carrier business models: The European case. Research in Transportation Business \& Management 21, 19-32.

Emrouznejad, A., \& Marra, M. (2017). The state of the art development of AHP (1979-2017): a literature review with a social network analysis. International Journal of Production Research, 55(22), 6653-6675.

European Low Fares Airline Association, 2015. Low fares airlines continue to grow from strength to strength.

Evangelho, F., Huse, C., Linhares, A., 2005. Market entry of a low cost airline and impacts on the Brazilian business travelers. Journal of Air Transport Management 11(2), 99-105.

Fageda, X., Suau-Sanchez, P., Mason, K.J., 2015. The evolving low-cost business model: Network implications of fare bundling and connecting flights in Europe. Journal of Air Transport Management 42, 289-296.

Forsyth, P., 2003. Low-cost carriers in Australia: experiences and impacts. Journal of Air Transport Management 9(5), 277-284.

Francis, G., Fidato, A., Humphreys, I., 2003. Airport-airline interaction: the impact of low-cost carriers on two European airports. Journal of Air Transport Management 9(4), 267-273. 
Fu, X., Lijesen, M., Oum, T.H., 2006. An Analysis of Airport Pricing and Regulation in the Presence of Competition Between Full Service Airlines and Low Cost Carriers. Journal of Transport Economics and Policy 40(3), 425-447

Gillen, D., Lall, A., 2004. Competitive advantage of low-cost carriers: some implications for airports. Journal of Air Transport Management 10(1), 41-50.

Gross, S., Lück, M., 2016. The Low Cost Carrier Worldwide. Routledge

Halpern, N., Graham, A., Dennis, N., 2016. Low cost carriers and the changing fortunes of airports in the UK. Research in Transportation Business \& Management 21, 33-43.

Hsu, C.-I., Wen, Y.-H., 2002. Reliability evaluation for airline network design in response to fluctuation in passenger demand. Omega 30(3), 197-213.

Humphreys, I., Francis, G., 2002. Policy issues and planning of UK regional airports. Journal of Transport Geography 10(4), 249-258.

Jones, O.C., Budd, L.C.S., Pitfield, D.E., 2013. Aeronautical charging policy incentive schemes for airlines at European airports. Journal of Air Transport Management 33, 43-59.

Kahraman, C., \& Kaya, İ. (2010). A fuzzy multicriteria methodology for selection among energy alternatives. Expert Systems with Applications, 37(9), 6270-6281.

Karaman, A. S., \& Akman, E. (2018). Taking-off corporate social responsibility programs: An AHP application in airline industry. Journal of Air Transport Management, 68, 187-197.

Kilincci, O., \& Onal, S. A. (2011). Fuzzy AHP approach for supplier selection in a washing machine company. Expert Systems with Applications, 38(8), 9656-9664.

Kim, D.-S., 2019. Jeju Air aims for customer-oriented business growth, The Korea Herald, South Korea. Perrett, B., 2018. Juneyao Airlines identifies Helsinki as first long-haul route, Air Transport World.

Klophaus, R., Conrady, R., Fichert, F., 2012. Low cost carriers going hybrid: Evidence from Europe. Journal of Air Transport Management 23, 54-58.

Loo, B.P.Y., 2008. Passengers' airport choice within multi-airport regions (MARs): some insights from a stated preference survey at Hong Kong International Airport. Journal of Transport Geography 16(2), 117-125.

Lu, J.-L., Choi, J.K., Tseng, W.-C., 2011. Determinants of passengers' choice of airline check-in services: A case study of American, Australian, Korean, and Taiwanese passengers. Journal of Air Transport Management 17(4), 249-252.

Malighetti, P., Paleari, S., Redondi, R., 2009. Pricing strategies of low-cost airlines: The Ryanair case study. Journal of Air Transport Management 15(4), 195-203.

Malina, R., Albers, S., Kroll, N., 2012. Airport Incentive Programmes: A European Perspective. Transport Reviews 32(4), 435-453.

Mason, K.J., Morrison, W.G., 2008. Towards a means of consistently comparing airline business models with an application to the 'low cost' airline sector. Research in Transportation Economics 24(1), 75-84.

Morandi, V., Malighetti, P., Paleari, S., Redondi, R., 2015. Codesharing agreements by low-cost carriers: an explorative analysis. Journal of Air Transport Management 42(1), 184-191.

Paliska, D., Drobne, S., Borruso, G., Gardina, M., Fabjan, D., 2016. Passengers' airport choice and airports' catchment area analysis in cross-border Upper Adriatic multi-airport region. Journal of Air Transport Management 57, 143-154.

Pitt, M.R., Brown, A.W., 2001. Developing a strategic direction for airports to enable the provision of services to both network and low-fare carriers. Facilities 19(1/2), 52-60.

Porter, M.E., Kramer, M.R., 2017. Creating shared value, Managing Sustainable Business. Springer, pp. 327-350.

Saaty, T. L. (2008). Decision making with the analytic hierarchy process. International Journal of Services Sciences, 1(1), 83-98.

Scheers, J., 2001. Attracting investors to European regional airports. What are the prerequisites? International Airport Review 5(4), 55-63.

Sofyalığlu, Ç., \& Kartal, B. (2012). The selection of global supply chain risk management strategies by using fuzzy analytical hierarchy process-a case from Turkey. Procedia-Social and Behavioral Sciences, 58, 1448-1457. 
Thanasupsin, K., Chaichana, S., Pliankarom, S., 2010. Factors Influencing Mode Selections of Lowcost Carriers and a Full-service Airline in Thailand. Transportation Journal 49(1), 35-47.

Toh, M., 2013. Analysis: Dedicated low-cost terminals not the best bet, FlightGlobal. FlightGlobal, Singapore.

Wang, Y., Jung, K. A., Yeo, G. T., \& Chou, C. C. (2014). Selecting a cruise port of call location using the fuzzy-AHP method: A case study in East Asia. Tourism Management, 42, 262-270.

Warnock-Smith, D., Potter, A., 2005. An exploratory study into airport choice factors for European low-cost airlines. Journal of Air Transport Management 11(6), 388-392.

Zhang, A., Hanaoka, S., Inamura, H., Ishikura, T., 2008. Low-cost carriers in Asia: Deregulation, regional liberalization and secondary airports. Research in Transportation Economics 24(1), 36-50. 
Appendix:

A1. Fuzzy Comparison Matrix of Airport Charges Sub-Factors

\begin{tabular}{|c|c|c|c|}
\hline \multirow{2}{*}{+2} & \multirow{2}{*}{$\begin{array}{l}\text { Airport } \\
\text { Costs (A1) }\end{array}$} & Flexibility in Negotiating & \multirow{2}{*}{$\begin{array}{l}\text { Incentives to Help } \\
\text { LCCs to Reduce } \\
\text { Costs (A3) }\end{array}$} \\
\hline & & $\begin{array}{l}\text { Airport Charges Deals } \\
\text { (A2) }\end{array}$ & \\
\hline Airport Costs & $\begin{array}{c}(1.00,1.00, \\
1.00)\end{array}$ & $(1.69,2.06,2.38)$ & $(1.59,1.98,2.40)$ \\
\hline Flexibility & $(0.42,0.49$ & $(1.00,1.00,1.00)$ & $(0.46,0.52,0.60)$ \\
\hline Negotiating & $0.59)$ & & \\
\hline Charges Deals & & & \\
\hline Incentives to & $(0.42,0.51$ & $(0.60,1.93,2.20)$ & $(1.00,1.00,1.00)$ \\
\hline LCCs to Reduce Costs & $0.63)$ & & \\
\hline
\end{tabular}

A2. Fuzzy Comparison Matrix of Catchment Area Sub-Factors

\begin{tabular}{lrcr}
\hline & \multicolumn{2}{c}{$\begin{array}{l}\text { Proximity } \\
\text { Populated/Tourist Areas (B1) }\end{array}$} & $\begin{array}{r}\text { to } \\
\text { (B2) }\end{array}$ \\
\hline $\begin{array}{l}\text { Proximity } \\
\text { Populated/Tourist Areas }\end{array}$ & $(1.00,1.00,1.00)$ & $(0.32,0.38,0.44)$ \\
$\begin{array}{l}\text { to } \\
\text { Demand for LCC }\end{array}$ & $(2.26,2.67,3.11)$ & $(1.00,1.00,1.00)$ \\
Services & & & \\
\hline
\end{tabular}

A3. Fuzzy Comparison Matrix of Airport Infrastructure Sub-Factors

\begin{tabular}{lcccc}
\hline & & $\begin{array}{c}\text { Availability of } \\
\text { Dedicated Facilities (C1) }\end{array}$ & $\begin{array}{l}\text { AcC } \\
\text { Accessibility (C2) }\end{array}$ \\
\hline $\begin{array}{l}\text { Availability } \\
\text { of }\end{array}$ & LCC & $(1.00,1.00,1.00)$ & $(1.41,1.68,1.94)$ \\
$\begin{array}{l}\text { Dedicated Facilities } \\
\text { Airport }\end{array}$ & Ground & $(0.52,0.59,0.71)$ & $(1.00,1.00,1.00)$ \\
Accessibility & & & \\
\hline
\end{tabular}

A4. Fuzzy Comparison Matrix of Airport Performance Sub-Factors 


\begin{tabular}{|c|c|c|c|c|c|}
\hline & $\begin{array}{l}\text { Efficiency } \\
\text { of Aircraft- } \\
\text { Related } \\
\text { Processes } \\
\text { (D1) }\end{array}$ & $\begin{array}{l}\text { Efficiency } \\
\text { of } \\
\text { Passenger- } \\
\text { Related } \\
\text { Processes } \\
\text { (D2) }\end{array}$ & $\begin{array}{l}\text { Previous } \\
\text { Experience } \\
\text { of LCCs } \\
\text { (D3) }\end{array}$ & $\begin{array}{l}\text { Non- } \\
\text { aeronautical } \\
\text { Revenues } \\
\text { (D4) }\end{array}$ & $\begin{array}{l}\text { Passenger } \\
\text { Throughput } \\
\text { (D5) }\end{array}$ \\
\hline $\begin{array}{l}\text { Efficiency of } \\
\text { Aircraft- } \\
\text { Related } \\
\text { Processes }\end{array}$ & $\begin{array}{c}(1.00,1.00 \\
1.00)\end{array}$ & $\begin{array}{c}(0.91,1.16 \\
1.44)\end{array}$ & $\begin{array}{c}(1.32,1.79, \\
2.28)\end{array}$ & $\begin{array}{c}(1.18,1.49, \\
1.82)\end{array}$ & $\begin{array}{c}(0.25,0.29, \\
0.38)\end{array}$ \\
\hline $\begin{array}{l}\text { Efficiency of } \\
\text { Passenger- } \\
\text { Related } \\
\text { Processes }\end{array}$ & $\begin{array}{c}(0.69,0.87 \\
1.10)\end{array}$ & $\begin{array}{c}(1.00,1.00 \\
1.00)\end{array}$ & $\begin{array}{c}(0.59,0.69 \\
0.83)\end{array}$ & $\begin{array}{c}(1.28,1.64 \\
2.06)\end{array}$ & $\begin{array}{c}(0.27,0.32 \\
0.39)\end{array}$ \\
\hline $\begin{array}{l}\text { Previous } \\
\text { Experience }\end{array}$ & $\begin{array}{c}(0.44,0.56 \\
0.76)\end{array}$ & $\begin{array}{c}(1.20,1.44 \\
1.69)\end{array}$ & $\begin{array}{c}(1.00,1.00, \\
1.00)\end{array}$ & $\begin{array}{c}(1.08,1.34 \\
1.62)\end{array}$ & $\begin{array}{c}(0.38,0.46 \\
0.60)\end{array}$ \\
\hline $\begin{array}{l}\text { Non- } \\
\text { aeronautical } \\
\text { Revenues }\end{array}$ & $\begin{array}{c}(0.55,0.67 \\
0.84)\end{array}$ & $\begin{array}{c}(0.49,0.61 \\
0.78)\end{array}$ & $\begin{array}{c}(0.62,0.75 \\
0.93)\end{array}$ & $\begin{array}{c}(1.00,1.00 \\
1.00)\end{array}$ & $\begin{array}{c}(0.28,0.34 \\
0.44)\end{array}$ \\
\hline $\begin{array}{l}\text { Passenger } \\
\text { Throughput }\end{array}$ & $\begin{array}{c}(2.65,3.34 \\
4.02)\end{array}$ & $\begin{array}{c}(2.51,3.15 \\
3.76)\end{array}$ & $\begin{array}{c}(1.66,2.15, \\
2.66)\end{array}$ & $\begin{array}{c}(2.26,2.94 \\
3.55)\end{array}$ & $\begin{array}{c}(1.00,1.00, \\
1.00)\end{array}$ \\
\hline
\end{tabular}

A5. Fuzzy Comparison Matrix of Airport Growth Opportunities Sub-Factors

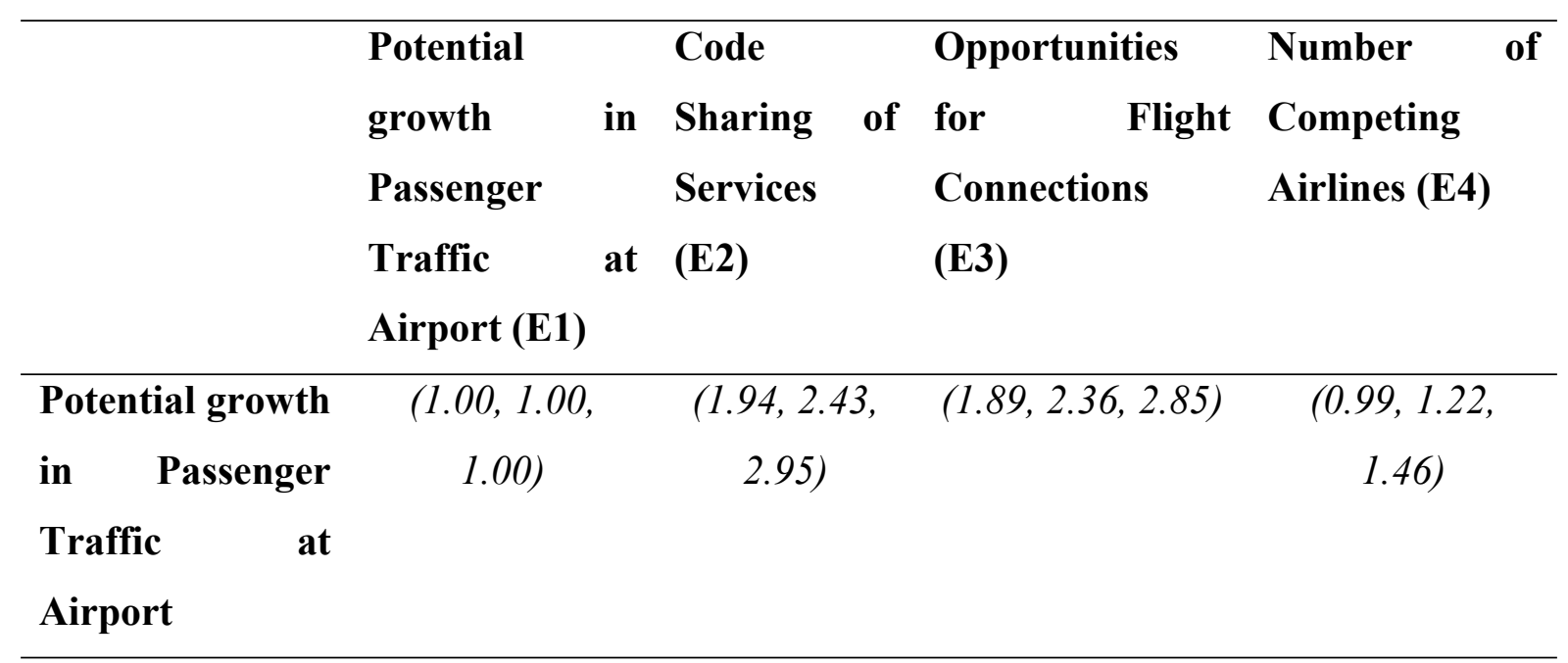




\begin{tabular}{lcccc}
\hline Code Sharing of & $(0.34,0.41$, & $(1.00,1.00$, & $(0.67,0.81,0.97)$ & $(0.43,0.52$, \\
$\begin{array}{l}\text { Services } \\
\text { Opportunities }\end{array}$ & $0.52)$ & $1.00)$ & & $0.62)$ \\
for Flight & $0.35,0.42$, & $(1.04,1.24$, & $(1.00,1.00,1.00)$ & $(0.49,0.60$, \\
$\begin{array}{l}\text { Connections } \\
\text { Number of }\end{array}$ & $(0.69,0.82$, & $(1.60)$ & & $0.75)$ \\
$\begin{array}{l}\text { Competing } \\
\text { Airlines }\end{array}$ & $1.00)$ & $2.35)$ & & $(1.05,1.00,1.00$, \\
\hline
\end{tabular}




\section{TABLES}

Table 1. Airport selection criteria for LCCs

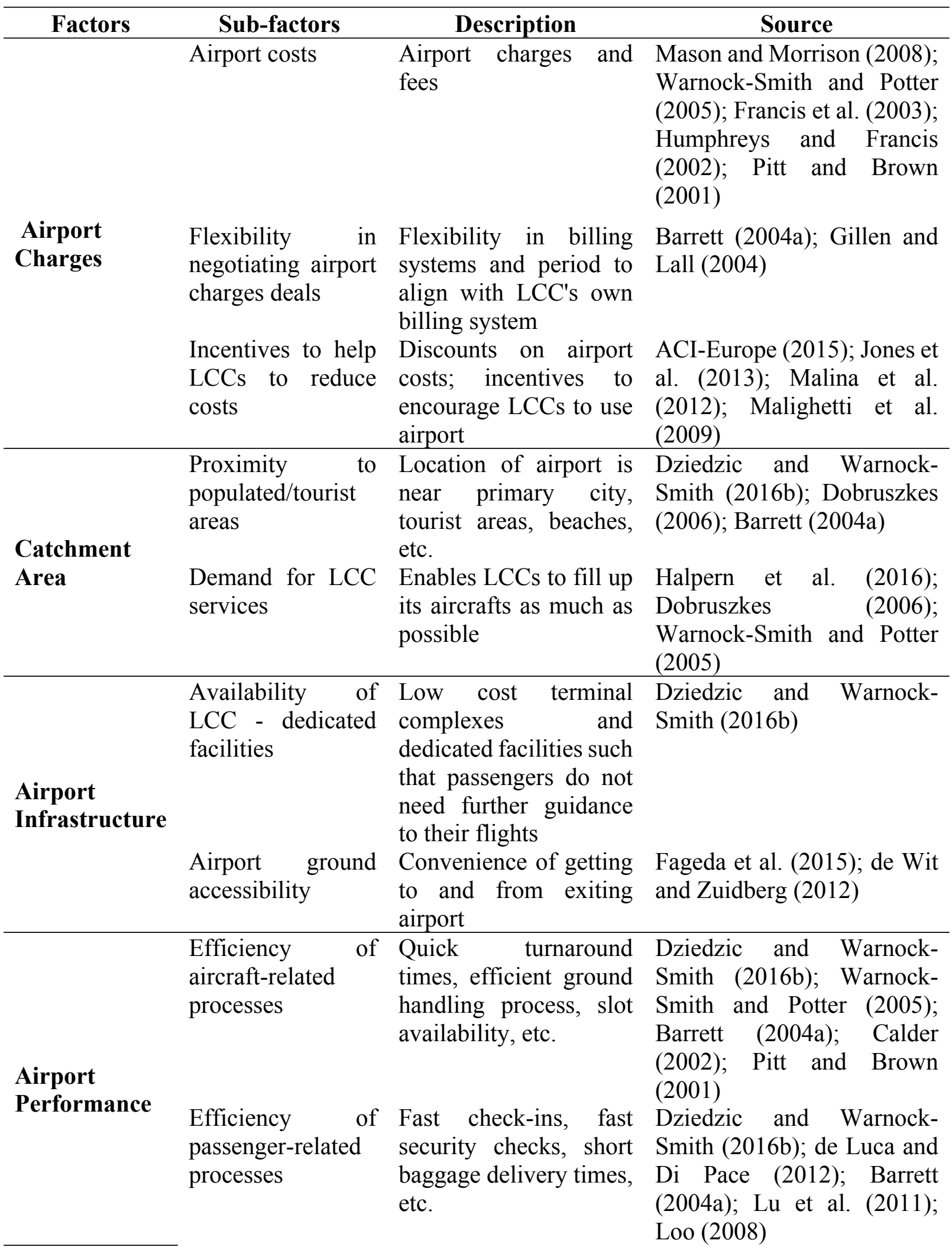




\begin{tabular}{|c|c|c|c|}
\hline & $\begin{array}{l}\text { Previous } \\
\text { experience } \\
\text { LCCs }\end{array}$ & $\begin{array}{l}\text { Airport has prior } \\
\text { experience of handling } \\
\text { LCCs }\end{array}$ & $\begin{array}{l}\text { Dziedzic and } \\
\text { Smith (2016b); }\end{array}$ \\
\hline & $\begin{array}{l}\text { Non-aeronautical } \\
\text { revenues }\end{array}$ & $\begin{array}{l}\text { Revenue from retail, } \\
\text { food and beverage and } \\
\text { other commercial } \\
\text { sources not related to } \\
\text { aeronautical earned } \\
\text { within the airport } \\
\text { complex. }\end{array}$ & $\begin{array}{l}\text { Dziedzic and Warnock- } \\
\text { Smith (2016b); }\end{array}$ \\
\hline & $\begin{array}{l}\text { Passenger } \\
\text { throughput }\end{array}$ & $\begin{array}{l}\text { Total number of } \\
\text { passengers handled per } \\
\text { year by airport }\end{array}$ & Halpern et al. (2016) \\
\hline \multirow{4}{*}{$\begin{array}{l}\text { Airport } \\
\text { Growth } \\
\text { Opportunities }\end{array}$} & $\begin{array}{l}\text { Potential growth in } \\
\text { passenger traffic at } \\
\text { airport }\end{array}$ & $\begin{array}{l}\text { Capacity at the airport } \\
\text { to accommodate future } \\
\text { passenger traffic }\end{array}$ & $\begin{array}{l}\text { Smith (2016b); Fageda et al. } \\
\text { (2015); Warnock-Smith and } \\
\text { Potter (2005) }\end{array}$ \\
\hline & $\begin{array}{l}\text { Code sharing of } \\
\text { services }\end{array}$ & $\begin{array}{ll}\text { Ability to execute } \\
\text { existing and } \\
\text { new code } & \text { sharing } \\
\text { partnerships } & \end{array}$ & $\begin{array}{l}\text { Fageda et al. (2015); } \\
\text { Halpern et al. (2016); De } \\
\text { Poret et al. (2015); de Wit } \\
\text { and Zuidberg (2012) }\end{array}$ \\
\hline & $\begin{array}{l}\text { Opportunities for } \\
\text { flight connections }\end{array}$ & $\begin{array}{l}\text { Opportunities for } \\
\text { increasing connectivity }\end{array}$ & \\
\hline & $\begin{array}{l}\text { Number of } \\
\text { competing airlines }\end{array}$ & $\begin{array}{l}\text { Power of LCC in } \\
\text { particular route, } \\
\text { possibility r of } \\
\text { monopolising routes }\end{array}$ & $\begin{array}{l}\text { Dziedzic and Warnock- } \\
\text { Smith (2016b); Mason and } \\
\text { Morrison (2008) }\end{array}$ \\
\hline
\end{tabular}

Resource: Compiled by authors

Table 2. Scale for pairwise comparisons

\begin{tabular}{cc}
\hline Intensity of Importance & Definition \\
\hline 1 & Equal importance \\
3 & Moderate importance \\
5 & Strong importance \\
7 & Very strong importance \\
9 & Absolute importance \\
$2,4,6,8$ & Intermediate values \\
\hline
\end{tabular}

Resource: Saaty (2008) 
Table 3. Profile of survey respondents

\begin{tabular}{llcc}
\hline $\begin{array}{l}\text { Profile of the survey } \\
\text { respondents }\end{array}$ & Range & Frequency & Percentage (\%) \\
\hline Job title & Director & 8 & 29 \\
& Manager & 15 & 54 \\
& Executive & 5 & 18 \\
Age (years) & $20-30$ & 3 & 11 \\
& $30-40$ & 15 & 54 \\
& Above 40 & 10 & 36 \\
Educational Level & Bachelor & 12 & 43 \\
& Master & 16 & 57 \\
Working experience (years) & $1-3$ & 3 & 11 \\
& $3-5$ & 5 & 18 \\
& $5-10$ & 8 & 29 \\
& Above 10 & 12 & 43 \\
\hline
\end{tabular}

Table 4. The 1-9 fuzzy conversion scale

\begin{tabular}{cccc}
\hline Scale & $\begin{array}{c}\text { Triangular Fuzzy } \\
\text { Scale }\end{array}$ & $\begin{array}{c}\text { Reciprocal } \\
\text { Scale }\end{array}$ & $\begin{array}{c}\text { Triangular Fuzzy } \\
\text { Reciprocal Scale }\end{array}$ \\
\hline 1 & $(1,1,1)$ & 1 & $(1 / 1,1 / 1,1 / 1)$ \\
2 & $(1,2,3)$ & $1 / 2$ & $(1 / 3,1 / 2,1 / 1)$ \\
3 & $(2,3,4)$ & $1 / 3$ & $(1 / 4,1 / 3,1 / 2)$ \\
4 & $(3,4,5)$ & $1 / 4$ & $(1 / 5,1 / 4,1 / 3)$ \\
5 & $(4,5,6)$ & $1 / 5$ & $(1 / 6,1 / 5,1 / 4)$ \\
6 & $(5,6,7)$ & $1 / 6$ & $(1 / 7,1 / 6,1 / 5)$ \\
7 & $(6,7,8)$ & $1 / 7$ & $(1 / 8,1 / 7,1 / 6)$ \\
8 & $(7,8,9)$ & $1 / 8$ & $(1 / 9,1 / 8,1 / 7)$ \\
9 & $(8,9,9)$ & $1 / 9$ & $(1 / 9,1 / 9,1 / 8)$ \\
\hline
\end{tabular}

Resource: Angnostopoulos et al. (2007)

Table 5. Fuzzy Comparison Matrix for Main Criteria 


\begin{tabular}{|c|c|c|c|c|c|}
\hline & $\begin{array}{l}\text { Airport } \\
\text { Charges } \\
\text { (F1) }\end{array}$ & $\begin{array}{l}\text { Catchment } \\
\text { Area (F2) }\end{array}$ & $\begin{array}{l}\text { Airport } \\
\text { Infrastructure } \\
\text { (F3) }\end{array}$ & $\begin{array}{l}\text { Airport } \\
\text { Performance } \\
\text { (F4) }\end{array}$ & $\begin{array}{l}\text { Airport } \\
\text { Growth } \\
\text { Opportunities } \\
\text { (F5) }\end{array}$ \\
\hline $\begin{array}{l}\text { Airport } \\
\text { Charges }\end{array}$ & $\begin{array}{l}(1.00, \\
1.00 \\
1.00)\end{array}$ & $\begin{array}{c}(0.93,1.13 \\
1.34)\end{array}$ & $\begin{array}{c}(2.38,2.75, \\
3.09)\end{array}$ & $\begin{array}{c}(1.83,2.17, \\
2.47)\end{array}$ & $\begin{array}{c}(1.14,1.34, \\
1.55)\end{array}$ \\
\hline $\begin{array}{l}\text { Catchment } \\
\text { Area }\end{array}$ & $\begin{array}{l}(0.75 \\
0.88 \\
1.08)\end{array}$ & $\begin{array}{c}(1.00,1.00) \\
1.00)\end{array}$ & $\begin{array}{c}(0.81,0.95 \\
1.11)\end{array}$ & $\begin{array}{c}(0.45,0.51, \\
0.59)\end{array}$ & $\begin{array}{c}(0.83,0.96 \\
1.18)\end{array}$ \\
\hline $\begin{array}{l}\text { Airport } \\
\text { Infrastructure }\end{array}$ & $\begin{array}{l}(0.32, \\
0.36 \\
0.42)\end{array}$ & $\begin{array}{c}(0.93,1.05 \\
1.24)\end{array}$ & $\begin{array}{c}(1.00,1.00, \\
1.00)\end{array}$ & $\begin{array}{c}(0.36,0.41, \\
0.48)\end{array}$ & $\begin{array}{c}(0.43,0.49 \\
0.57)\end{array}$ \\
\hline $\begin{array}{l}\text { Airport } \\
\text { Performance }\end{array}$ & $\begin{array}{l}(0.41 \\
0.46 \\
0.55)\end{array}$ & $\begin{array}{c}(1.69,1.96 \\
2.21)\end{array}$ & $\begin{array}{c}(2.07,2.43, \\
2.78)\end{array}$ & $\begin{array}{c}(1.00,1.00, \\
1.00)\end{array}$ & $\begin{array}{c}(0.61,0.72, \\
0.85)\end{array}$ \\
\hline $\begin{array}{l}\text { Airport } \\
\text { Growth }\end{array}$ & $\begin{array}{l}(0.64 \\
0.75\end{array}$ & $\begin{array}{c}(0.89,1.03 \\
1.21)\end{array}$ & $\begin{array}{c}(1.73,2.05, \\
2.35)\end{array}$ & $\begin{array}{c}(1.18,1.39, \\
1.64)\end{array}$ & $\begin{array}{c}(1.00,1.00, \\
1.00)\end{array}$ \\
\hline Opportunities & $0.88)$ & & & & \\
\hline
\end{tabular}

Table 6. Ranking of Individual Criteria

\begin{tabular}{clc}
\hline Rank & \multicolumn{1}{c}{ Criteria } & Fuzzy Weight \\
\hline 1 & Airport Charges (F1) & 0.29 \\
2 & Airport Performance (F4) & 0.23 \\
3 & Airport Growth Opportunities (F5) & 0.22 \\
4 & Catchment Area (F2) & 0.15 \\
5 & Airport Infrastructure (F3) & 0.11 \\
\hline
\end{tabular}

Table 7. Overall Ranking 


\begin{tabular}{|c|c|c|c|c|c|}
\hline Ranking & Criteria & Sub-Criteria & $\begin{array}{l}\text { Criteria } \\
\text { Weight }\end{array}$ & $\begin{array}{c}\text { Sub- } \\
\text { Criteria } \\
\text { Weight }\end{array}$ & $\begin{array}{l}\text { Overall } \\
\text { Ranking }\end{array}$ \\
\hline 1 & $\begin{array}{l}\text { Airport Charges } \\
\text { (F1) }\end{array}$ & Airport costs (A1) & 0.29 & 0.49 & 0.142 \\
\hline 2 & $\begin{array}{l}\text { Catchment Area } \\
\text { (F2) }\end{array}$ & $\begin{array}{c}\text { Demand for LCC } \\
\text { services (B2) }\end{array}$ & 0.15 & 0.73 & 0.1095 \\
\hline 3 & $\begin{array}{c}\text { Airport } \\
\text { Performance } \\
\text { (F4) }\end{array}$ & $\begin{array}{l}\text { Passenger throughput } \\
\text { (D5) }\end{array}$ & 0.23 & 0.41 & 0.094 \\
\hline 4 & $\begin{array}{c}\text { Airport Charges } \\
\text { (F1) }\end{array}$ & $\begin{array}{l}\text { Incentives to help } \\
\text { LCCs to reduce costs } \\
\text { (A3) }\end{array}$ & 0.29 & 0.31 & 0.089 \\
\hline 5 & $\begin{array}{l}\text { Airport Growth } \\
\text { Opportunities } \\
\text { (F5) }\end{array}$ & $\begin{array}{l}\text { Potential growth in } \\
\text { passenger traffic at } \\
\text { airport (E1) }\end{array}$ & 0.22 & 0.38 & 0.0836 \\
\hline 6 & $\begin{array}{c}\text { Airport } \\
\text { Infrastructure } \\
\text { (F3) }\end{array}$ & $\begin{array}{l}\text { Availability of LCC - } \\
\text { dedicated facilities } \\
\text { (C1) }\end{array}$ & 0.11 & 0.63 & 0.0693 \\
\hline 7 & $\begin{array}{l}\text { Airport Growth } \\
\text { Opportunities } \\
\text { (F5) }\end{array}$ & $\begin{array}{c}\text { Number of competing } \\
\text { airlines (E4) }\end{array}$ & 0.22 & 0.30 & 0.066 \\
\hline 8 & $\begin{array}{c}\text { Airport Charges } \\
\text { (F1) }\end{array}$ & $\begin{array}{c}\text { Flexibility in } \\
\text { negotiating airport } \\
\text { charges deals (A2) }\end{array}$ & 0.29 & 0.20 & 0.058 \\
\hline 9 & $\begin{array}{c}\text { Airport } \\
\text { Performance } \\
\text { (F4) }\end{array}$ & $\begin{array}{l}\text { Efficiency of aircraft- } \\
\text { related processes } \\
\text { (D1) }\end{array}$ & 0.23 & 0.18 & 0.0414 \\
\hline 10 & $\begin{array}{c}\text { Airport } \\
\text { Infrastructure } \\
\text { (F3) }\end{array}$ & $\begin{array}{c}\text { Airport ground } \\
\text { accessibility (C2) }\end{array}$ & 0.11 & 0.37 & 0.0407 \\
\hline
\end{tabular}




\begin{tabular}{|c|c|c|c|c|c|}
\hline Ranking & Criteria & Sub-Criteria & $\begin{array}{l}\text { Criteria } \\
\text { Weight }\end{array}$ & $\begin{array}{c}\text { Sub- } \\
\text { Criteria } \\
\text { Weight }\end{array}$ & $\begin{array}{l}\text { Overall } \\
\text { Ranking }\end{array}$ \\
\hline 11 & $\begin{array}{c}\text { Catchment Area } \\
\text { (F2) }\end{array}$ & $\begin{array}{c}\text { Proximity to } \\
\text { populated/tourist } \\
\text { areas (B1) }\end{array}$ & 0.15 & 0.27 & 0.0405 \\
\hline 12 & $\begin{array}{c}\text { Airport Growth } \\
\text { Opportunities } \\
\text { (F5) }\end{array}$ & $\begin{array}{l}\text { Opportunities for } \\
\text { flight connections } \\
\text { (E3) }\end{array}$ & 0.22 & 0.18 & 0.0396 \\
\hline 13 & $\begin{array}{c}\text { Airport } \\
\text { Performance } \\
\text { (F4) }\end{array}$ & $\begin{array}{c}\text { Previous experience } \\
\text { of LCCs (D3) }\end{array}$ & 0.23 & 0.16 & 0.0368 \\
\hline 14 & $\begin{array}{c}\text { Airport } \\
\text { Performance } \\
\text { (F4) }\end{array}$ & $\begin{array}{c}\text { Efficiency of } \\
\text { passenger-related } \\
\text { processes (D2) }\end{array}$ & 0.23 & 0.15 & 0.0345 \\
\hline 15 & $\begin{array}{c}\text { Airport Growth } \\
\text { Opportunities } \\
\text { (F5) }\end{array}$ & $\begin{array}{l}\text { Codesharing of } \\
\text { services (E2) }\end{array}$ & 0.22 & 0.15 & 0.033 \\
\hline 16 & $\begin{array}{c}\text { Airport } \\
\text { Performance } \\
\text { (F4) }\end{array}$ & $\begin{array}{c}\text { Non-aeronautical } \\
\text { revenues (D4) }\end{array}$ & 0.23 & 0.11 & 0.0253 \\
\hline
\end{tabular}


Hui Shan Loh: Writing - Original \& Review Kum Fai Yuen: Conceptualization, Writing Original \& Review, Project administration Xueqin Wang: Writing - Original \& Review Ebru SÜRÜCÜ-BALCI, Gökcay BALCI, \& Qingji ZHOU: Formal analysis, methodology, visualisation 